\title{
Leaving Hinduism: Deconversion as Liberation
}

\author{
Michael Stausberg
}

\section{Introduction}

Leaving one religion, and in its place committing to another one, tends to appear as two sides of one coin, or as two steps in one process. Conversion narratives typically emphasise dissatisfaction with and imperfections of the former and the superiority of the new religion respectively. Another model of conversion is the adoption of a religious self-assertion by previously religiously uncommitted persons who discover religion and a religion; or, alternatively, the dissolution of a religious identification and the adoption of a non-religious one; for example, former religious believers now profess new identities as humanists or atheists. Leaving religion, however, is not the same as leaving a religion.

In this chapter, we will consider the case of a public person who decided to leave Hinduism, the religion he was thrown into by birth in colonial Western India. The decision to leave this religion, however, did not emerge in the process of converting to another religion, nor did he leave religion altogether - in fact, he did not profess to be non- or anti-religious but he found religion useful and necessary. Apparently, he was not tempted to create a religion of his own making. Instead he proceeded to adopt some already extant religion, but this protracted or retarded quest for the religion he would adopt went on over several decades. The religion he and several hundred thousand of his followers adopted eventually, Buddhism, was being remade in the process. The person is question was Dr. Bhimrao Ambedkar (1891-1956), often hailed as the 'father of the Indian constitution'.

The life and work of Ambedkar has previously been discussed, for example, by Djananjay Keer (1971), Gauri Viswanathan (1998), Johannes Beltz (2005), Cristophe Jaffrelot (2005), and Pandey Gyanendra (2006), from historical, anthropological, sociological and political science perspectives (see also Jondhale and Beltz 2005). This chapter presents a biographical sketch of Amdebkar 
[based on Keer (1971); Jaffrelot (2005); Zelliot (2013)] and analyses the background and reasons for his decision to leave Hinduism, and his adoption of a new religious identity. As primary sources, the chapter draws on his writings and speeches.

Bhimrao Ambedkar was born into a Mahar family. The West Indian Mahars were treated as what was then called "untouchables," a word that many today seek to avoid as it carries stigma. An alternative word for untouchables is dalit (Marathi for "broken men"), a term introduced by Ambedkar and popularised by his later followers. In the writings that concern us here, however, Ambedkar spoke of untouchables, untouchability, or depressed classes - and this is the terminology used here when speaking about Ambedkar, to capture the stigma he sought to get rid of.

In later texts, Ambedkar recalls that growing up as an untouchable imposed "certain indignities and discriminations" (Ambedkar 2002: 52). Here are some of the examples he provides: in school he had to sit in a corner by himself, where he sat on a piece of gunny cloth that the servant employed to cleanse the room would not touch. When thirsty, he could not get out and tap water, but the water had to be tapped for him by a specific worker, so that he would go thirsty if that person was not around. No washer would wash the clothes of an untouchable, nor would any barber shave or cut his hair. While this was an unquestioned part of their everyday life-world, the exceptionality of these rules dawned on him during a nightmarish trip to visit his father (who worked in a different village), where he and his relatives was denied decent transportation, assistance, and water.

During British rule, relatively many Mahars were recruited into the army. This opened opportunities for education. Ambedkar's father was the instructor of a local military school. It seems that Ambedkar was a brilliant student, so much so that his teacher let him adopt his own surname instead of his previous one (Ambadve, after his village of origin in Bombay Province) (Zelliot 2013: 67). In 1904, the family moved to Bombay (Mumbai), where Ambedkar could advance his education. In 1912, he completed his B.A. from Elphinstone College with Persian and English as his subjects. Even though this college was a government school, given his background he was denied the opportunity to study Sanskrit. Sayajirao Gaekwad III (born Shrimant Gopalrao Gaekwad), the reform-minded Maharaja of Baroda State, awarded him a scholarship that allowed him to go abroad and study at Columbia University. There he studied with the philosopher John Dewey, the economist Edwin Seligman and the social anthropologist Alexander Goldenweiser, a student of Franz Boas. One of his student papers - a critical investigation of caste - was subsequently published in an Indian academic periodical. In line with Boasian theory, Ambedkar did not view caste as a result of race but theorised caste as a cultural 
phenomenon (Cháirez-Garza 2018). At Columbia, he completed an M.A. degree and was awarded a Ph.D. He continued his education in London for one year. In 1917, however, having returned to India, it was impossible for him to work in the administration in Baroda since his colleagues refused any form of collaboration and intercourse with an untouchable. In Bombay, he became a political activist and a journalist. In 1920 he returned to London to complete his education, obtaining an M.Sc. (1922) and a D.Sc. (1923). He was one of the best educated Indians of his time, and the best educated untouchable ever.

In 1922, Ambedkar was called to the Bar at Grey's Inn, London. This opened a professional mainstay for him after his return to India in 1923. Henceforth, he practiceed law for a living, and for some periods of his life he taught law. The knowledge of law was an important asset for him in his manifold campaigns for the emancipation of the untouchables from their oppression. Among of his strategies of emancipation were the introduction of new laws, the revision of extant legislation, or opposition to proposed bills. After the war, Ambedkar's expertise as a lawyer qualified him to become, in 1947, India's first law minister and to draft the constitution of independent India that was adopted in 1949. Paragraph 17 of this constitution formally abolished untouchability and turned the practice of it into a crime:

"Untouchability" is abolished and its practice in any form is forbidden. The enforcement of any disability arising out of "Untouchability" shall be an offence punishable in accordance with law. ${ }^{1}$

Unfortunately, this legal stipulation, which does not define "untouchability," did not uproot the resilience of the concept and the practice. ${ }^{2}$ This was one factor, it could seem, that led Ambedkar to take a dramatic religious step towards the end of his life.

Over the decades Ambedkar unfolded various activities aiming to set the untouchables free from the bonds of discrimination. Among other activities, he acted as speaker, author, publisher, organiser, politician, educator. His career as an activist went along with a concern for theory; Ambedkar was a major sociologist and theoretician of caste and democracy - and as we shall see, a theoretician of religion.

1 https://www.india.gov.in/sites/upload_files/npi/files/coi_part_full.pdf (accessed 03/o7/2019).

2 Even in the present age, Dalits continue to be oppressed, killed, gang-raped, amputated, paraded naked, forced to eat shit, boycotted; their land is seized and access to drinking water is denied to them. The legal system systematically defines caste as a factor out of the picture when dealing with cases of violence against Dalits (see Roy in Ambedkar 2014b). 
In modern Indian history Ambedkar is often recalled as an antagonist of Mohandas (Mahatma) Gandhi. ${ }^{3}$ Their relationship turned into open conflict in 1931, at the Second Round Table Conference in London. These conferences were a platform organised by the British government to discuss matters of constitutional reforms in India. Gandhi had negotiated to be the sole representative of the Indian National Congress, and Ambedkar was one of two appointed representatives of the so-called Depressed Classes. Their dispute escalated during the following year over the matter of a separate electorate for the Depressed Classes. To Ambedkar, denying the untouchables a separate electorate would place them under the dominion of the caste-Hindus, while Gandhi feared a split within the Hindu electorate. The debate by implication centered on whether the untouchables were a part of Hinduism or Hindu society, or whether the segregation and discrimination imposed on the untouchables by the caste-Hindus made them a separate entity; Gandhi held the former view, Ambedkar the latter. This division would resurface in the issue of deconversion. For the next fifteen years or so, Ambedkar and Gandhi occasionally engaged in controversy. As late as in 1946, Ambedkar published a book with the title What Congress and Gandhi have done to the Untouchables, where he dismisses Gandhi's economics and his view of society. One issue in their dispute was the nature and function of Hinduism. While Gandhi was a major apologist of Hinduism - or his interpretation thereof -, Ambedkar came to reject Hinduism as "a veritable chamber of horrors," as he put in it this book.

The relationships of untouchables to Hinduism was at the same time one of inclusion and one of exclusion. On this view, by imposing a social order based on its ideological structure, Hinduism imprisons the untouchables within a cage of rules and regulations. At the same time, these same rules and regulations exclude them from basic rights and facilities, including religious ones. For example, untouchables were not admitted to Hindu temples. Accordingly, campaigns in which Ambedkar played a part dealt with one of the foundational texts for Hindu law and the problem of temple entrance.

These two issues - the ideological basis and the practice of exclusion - were targeted since around 1927. At a conference that Ambedkar opened in December 1927, a resolution was declared that affirmed the rights of the untouchables and that condemned Hindu scriptures, which authorise social inequality. There, Ambedkar took the radical step of burning the Manusmriti publicly, in full sight of the participants. In the month prior to this act he had studied

3 See Coward (2003) for their respective positions on untouchability. 
the Manusmriti with a pundit and a school-teacher. In an Indian context this act is unprecedented and it came as a shock to many (including supporters of his agenda). The idea for this had not originally been his. The conference passed four resolutions: "a declaration of human rights, a repudiation of the Manismriti, a demand that Hindu society be reduced to one class, and an advocation that the priestly profession be open to all." (Zelliot 2013: 81)

While this has been an isolated act, in November 1927 Ambedkar let himself get involved in a movement that demanded entry to Hindu temples in different locations in the Bombay Presidency. Not all of these campaigns were planned properly, and they failed in their aim to change temple policies. Authorities would rather close off temples to all worshippers than admitting untouchables. Following a Gandhian terminology and pattern these campaigns were called satyagraha. They used Gandhian symbolism (Rao 2009: 100), but they were not instigated by Gandhi, and Gandhi initially neither endorsed nor supported them. At a mass gathering in 1930 in the campaign to enter the Kalaram temple in Nasik, Ambedkar told the participants (in Marathi):

Today's satyagraha is a challenge to the Hindu mind. Are the Hindus ready to consider us men or not; we will discover this today ... We know that the god in the temple is of stone. Darshan and puja will not solve our problems. But we will start out, and try to make a change in the minds of the Hindus.

ZELLIOT 2013: 88

This statement makes it clear that the campaign does not primarily focus on religion; it does not aim at benefitting from the presumed religious efficacy of the temple. Even though withholding this religious benefit was perceived as unjust, Ambedkar expressed the conviction that religion will not resolve the problems of the untouchables - the temple access was not meant to provide supernatural intervention; he even went so far as to exclude this possibility by proclaiming the temple as dead ("the god ... is of stone"). For Ambedkar, the temple campaign was not a matter of faith. The satyagraha was more a matter of establishing his leadership, making moral claims and mobilising the untouchables behind a common cause that was able to stir emotions. The unfolding of the campaigns showed the reluctance of the government and the Indian National Congress to change the practice of exclusion. The satyagraha was a provocative social experiment. Its ultimate aim was to initiate a change in the mindset of the Hindus; without such a change in collective psychology, Ambedkar thought, there was no chance of the untouchables ever to become accepted as equal. 
In 1934, Ambedkar stated (in Marathi):

I would advise the Depressed Class to insist upon a complete overhauling of Hindu society and Hindu theology before they consent to become an integral part of Hindu Society. I started temple entry Satyagraha only because it was the best way of energising the Depressed Class and making them conscious of their position.

ZELLIOT 2013: 90

The temple entry campaign was an exercise in creating a class conscience. Even if it would have achieved its apparent goal of allowing untouchables to enter Hindu temples and there to worship Hindu deities, this would have only been a first and modest step. For achieving recognition and respect, liberty, equality and integration of the untouchables - namely the disintegration of the social category and categorisation of untouchability - would require a complete transformation of Hinduism in its ideological, social, political, and economic dimensions.

Ambedkar's support of the temple entry movement slackened since 1932/1933, when Gandhi started to support this cause and when it became a more widely shared goal - bringing with it the threat that it was once again caste-Hindus who would define Hinduism. For Ambedkar temple entrance really was a side issue; education, employment and economic advance were much more important. He also suspected that temple entrance gave undue symbolic prestige to high-caste and orthodox Hinduism (Diks 2001: 324). Rather than reforming Hinduism, Ambedkar came to reject it altogether - and consequently he ceased to support the temple entrance movement.

In May 1935, Ambedkar's first wife (Ramabai) passed away. In June he was appointed Principal of the Government Law College in Bombay. In October he spoke at the Bombay Presidency Depressed Classes Conference in Yeola, a small town some 70 kilometers East of Nasik. In this speech, which lasted for an hour and a half, in front of some ten thousand listeners he said (in Marathi):

Because we have the misfortune of calling ourselves Hindus, we are treated thus. If we were members of another Faith, none would dare treat us such. Choose any religion which gives you equality of status and treatment. We shall repair our mistake now. I had the misfortune of being born with the stigma of an Untouchable. However, it is not my fault; but I will not die a Hindu, for that it is in my power. 
There is an interesting shift from the plural to the singular in this passage. Ambedkar first addresses a collective entity ("we"), which suffers injustice just for being "called" Hindus and being treated according to this nominal classification. This collective entity is about to assume agency, and this implies the acceptance of responsibility: that others treat the untouchables as they do is a result of the untouchables' own "mistake," namely that they call themselves Hindus. Before the untouchables collective assume responsibility and agency, however, Ambedkar as an individual ("I") takes this step of interrupting the chain of events that leads from birth to death; while he could not help being thrown into the world as an untouchable, he can achieve an exit from this unfortunate trajectory. By way of example, Ambedkar made it clear that leaving Hinduism was an individual choice and decision. That he "will not die a Hindu" announces his step of leaving Hinduism; this announcement is ambiguous: did he declare an intention (that does not need to be executed) or did he execute a performative act?

The announcement itself was scandalous - and Gandhi was scandalised. He called Ambedkar's speech "unbelievable" and denied the feasibility or possibility of deliberately changing one's religion: "religion is not like a house or a cloak which can be changed at will" (Zelliot 2013: 148). Ambedkar responded by saying that his was "a deeply deliberated decision". The only uncertainty was: "What religion we shall belong to we have not yet decided". Ambedkar also made it clear that this was his individual decision and as such it was independent on what his followers would do:

I have made up my mind to change my religion. I do not care if the masses do not come. It is for them to decide ...

ZELLIOT 2013: 148

His Yeola speech did not remain an isolated incident. At the Poona Depressed Classes Youth Conference in January 1936 Ambedkar once again confirmed his resolve to leave Hinduism (Zelliot 2013: 150). In May 1936 this was followed by further public pronouncements. At the All-Bombay District Mahar Conference he composed a kind of litany in Marathi verse, which was printed under the title Mukti Kon Pathe? ("What Path to Liberation?") The first verses read as follows (in Eleanor Zelliot's English translation [2013: 154]):

Religion is for man; man is not for religion.

If you want to gain humanity (manuski), change your religion.

If you want to create a cooperating society, change your religion.

If you want power, change religion. 
If you want equality, change your religion.

If you want independence, change your religion.

If you want to make the world in which you live happy, change your religion.

The first verse - a famous Ambedkar-quote - denaturalises and demataphysises religion. If religion becomes a good for humanity and humanity becomes the subject rather than the object of religion, changing religion becomes an option. It even becomes a legitimate option if this serves positive aims, goals and values, such as the ones listed in the following verses (humanity, sociality, empowerment, equality, independence, happiness). The poem does not recommend any given alternative religion, but it presents a severe critique of Hinduism as a religion; even though Hinduism is not mentioned, everyone would know that this was the religion addressed as "a religion" in the following verses phrased as questions:

Why should you remain in a religion that does not let you enter its temples?

Why should you remain in a religion that does not give you water to drink?

Why should you remain in a religion that does not let you become educated?

Ambedkar goes one step further by denying that such a religion - that is, Hinduism - is a religion at all:

That religion which forbids humanitarian behavior between man and man is not a religion but a reckless penalty.

That religion which regards the recognition of man's humanity a sin is not a religion but a sickness.

That religion which allows one to touch a foul animal but not a man is not a religion but a madness.

In May 1936 Ambedkar was invited to give a speech at a forum for social reforms in Lahore. When this organisation asked Ambedkar to omit certain passages of his speech that it deemed too radical, Ambedkar decided not to give the speech. Instead, he had it printed as a booklet under the title The Annihilation of Caste, which has become one of his most well-known and often reprinted 
works (annotated and critical edition: Ambedkar 2014b). Ambedkar shows that caste, which divides humanity in different groups and puts these into a hierarchical order, is "a harmful institution" (Ambedkar 2002: 264; Ambedkar 2014b: 19) in economic terms, that it disrupts Hindu society because it prevents cooperation across the different castes and that it goes against the triad of liberty, equality and fraternity - guiding principles that he, together with justice, later came to enshrine in the preamble of the Constitution of India. Caste contributes to indifference and kills the public spirit. Ambedkar holds that caste is "a notion, ... a state of mind" (Ambedkar 2002: 289; Ambedkar 2014b: 51). Abolishing caste therefore requires a change of mindset. Ambedkar argues that caste can also be found in other religions, but that caste has a different status in Hinduism: it alone has imbued caste with an aura of "sacredness and divinity" (Ambedkar 2002: 291; Ambedkar 2014b: 53) and the status and fate of the Brahmins are tied to caste. For Ambedkar, caste is a fundamental part of Hinduism; Hindus "observe caste because they are deeply religious. In my view, what is wrong is their religion, which has inculcated the notion of caste." (Ambedkar 2002: 289; Ambedkar 2014b: 51) This religion needs to be destroyed in order to abolish caste and its fateful consequences. Contrary to his other pronouncements, however, in this speech Ambedkar does not advocate leaving Hinduism, but of destroying parts of it: "The real remedy is to destroy the belief in the sanctity of the Shastras." Or: "You must destroy the religion of the Shrutis and the Smirtis. Nothing else will avail." (Ambedkar 2002: 290, 297f; Ambedkar 2014b: 51, 62) Consequently, in this speech, which was not directed to the Mahars, he outlines a program of how to remedy Hinduism. This version of Hinduism would be based on the Upanishads. This would not be a superficial repair but a complete transformation of its outlook. This would be to "kill Brahminism" and to "give a new doctrinal basis to your religion-a basis that will be in consonance with Liberty, Equality and Fraternity, in short, with Democracy." (Ambedkar 2002: 301; Ambedkar 2014b: 66f) Note that he here speaks of "your religion," as if this were no longer his own religion - or because he did not address his fellow Mahars. So, whereas he has already left Hinduism behind, for those who do not wish to take such a step, he outlines an alternative cure. Towards the end of the book, invoking John Dewey, he states:

... the Hindus must consider whether the time has not come for them to recognise that there is nothing fixed, nothing external, nothing sanatan; that everything is changing, that change is the law of life for individuals as well as for society.

AMBEDKAR 2002: 304; AMBEDKAR 2014b: 69 
That Ambedkar announced his leaving Hinduism, did not mean that he wished to turn his back on religion. In The Annihilation of Caste Ambedkar distinguished between rules as prescriptions for doing things and principles as intellectual methods of judging things - and between a religion of rules and a religion of principles. For Ambedkar, Hinduism "is nothing but a multitude of commands and prohibitions" (298), a "legalised class-ethics" or "code of ordinances" (299). It is a religion of rules. But a religion of rules is not really a religion:

religion must mainly be a matter of principles only. It cannot be a matter of rules. The moment it degenerates into rules it ceases to be Religion, as it kills responsibility, which is the essence of a truly religious act.

AMBEDKAR 2002: 298

A religion of rules is not a religion, but law. Therefore, "there is nothing irreligious in working for the destruction of such a religion. Indeed I hold that it is your bounden duty to tear the mask, to remove the misrepresentation that is caused by misnaming this law as religion." (Ambedkar 2002: 299) One difference between law and religion lies in the respective perception of changeability: while it is accepted that laws can be abolished, changed or amended, "the idea of religion is generally speaking not associated with the idea of change"; so, treating rules as if they were religion makes them immune to change (Ambedkar 2002: 299). As we have seen, this is precisely what Ambedkar wishes to challenge.

At the same time, he makes it clear: "While I condemn a Religion of Rules, I must not be understood to hold the opinion that there is no necessity for a religion." (Ambedkar 2002: 300) He refers to a statement ascribed to Edmund Burke that "true religion is the foundation of society" (Ambedkar 2002: 300).

In the aftermath of the events of 1936 Ambedkar wrote a text, published in 1989 as "Away from the Hindus" in volume five of Ambedkar's Writings and Speeches compiled by Vasant Moon (Ambedkar 2014a: 403-421; Ambedkar 2002: 219-238). In this text, Ambedkar provides a critical examination of four objections raised by opponents against deconversion such as Gandhi. (Ambedkar speaks of conversion, but deconversion seems more appropriate as it is the leaving of Hinduism that is in the focus, not the adoption of another religion.) These common objections are summarised as follows:

1. What can the Untouchables gain by conversion? Conversion can make no change in the status of the Untouchables. 
2. All religions are true, all religions are good. To change religion is a futility.

3. The conversion of the Untouchables is political in its nature.

4. The conversion of the Untouchables is nit genuine as it is not based on faith. (Ambedkar 2002: 219)

Ambedkar starts with the fourth objection and holds that, historically speaking, conversions "without any religious motive" (2002: 220) are the rule rather than the exception. Ambedkar here refers to mass conversions, not to individual ones, it seems. Since the (de)conversion of the Untouchables "would take place after full deliberation of the value of religion and the virtue of the different religions," it actually "would be the first case in history of genuine conversion." (221) The third objection is dismissed as he holds that (de)conversion would not automatically bring about political rights (221). As to the second objection Ambedkar concedes that all religions may in fact be alike "in that they all teach that the meaning of life is to be found in the pursuit of "good," but asserts that "religions are not alike in their answers to this question 'What is good?' In this they certainly differ". (222) In this context, he appreciates and is critical of the comparative study of religion. On the one hand he acknowledges the relativising effect of methodological egalitarianism in the comparative study of religion:

The science of comparative religion has broken down the arrogant claims of all revealed religions that they alone are true and all others which are not the results of revelation are false. (222)

He acknowledges that by unmasking a distinction between true and false religion on the criteria of revelation as arbitrary and capricious "the science of comparative religion" has rendered a "great service ... to the cause of religion" (223). For Ambedkar the methodological critique of claims of religious superiority or supremacy has had a liberating effect, not from religion, but for religion.

On the other hand, Ambedkar voices the criticism that this attitude has had a relativising aspect that disenables the comparative study of religion to mark important differences:

But it must be said to the discredit of that science that it has created the general impression that all religions are good and there is no use and purpose in discriminating them. (223)

The critique of comparative religion as an academic discipline is twofold. First, there is its presumed uncritical pro-religious attitude, which fails to 
acknowledge the negative aspects of religion - such as the disastrous effects of the Hindu caste ideology on the untouchables. Second, he believed that the methodological egalitarianism of comparative religion has blinded it to the need to make distinctions between religion based on values or principles.

In addressing the second objection to conversion, Ambedkar already starts addressing the nature of religion. Religion appears as an authority defining what is good and a "motive force for the promotion and spread of the 'good" (222). Hence, religion has an ambivalent power: if the aim ('good') in question is destructive - as the caste system in Hinduism - religion advances its spread, which in this case is a bad thing. If, however, religion would define a positive, constructive value ('good') religion would contribute to its advancement, which would be a good thing. To substantiate this ambivalence he refers to Cornelis Tiele (222).

Ambedkar's discussion of the first objection to conversion results in a discussion of the function and purposes of religion. Unlike a Marxian reading that considers religion as an Überbau (superstructure) he finds it to be a kind of Unterbau (substructure or foundational structure) of society and societal life. In his discussion he cites a range of Western theoreticians such as Dewey, William Robertson Smith, Ernest Crawley, the sociologist Charles Ellwood and the psychologist William McDougall. (No Indian thinkers are cited.) Drawing on this body of theory, Ambedkar seeks to dismiss some common notions of religion: it was mistaken, for Ambedkar, "to think of religion as though it was supernatural" (223) - recall his refutation of the supernatural reality of deities in the stone of Hindu temples. Moreover, he thinks one should not "look upon religion as a matter which is individual, private and personal" (225). Instead, "the primary content of religion is social" (223), and "life and the preservation of life constitute the essence of religion" (224). Like language, religion "is social for the reason that either is essential for social life and the individual has to have it because without it he cannot participate in the life of the society." (225) As an institution that centres on life and that allows participation in society - none being the case with Hinduism for the untouchables - religion operates like a kind of kinship community structure, which it enacts in shared ritual drinks and meals (235), a thought that seems to be inspired by Robertson Smith.

In his posthumously published work The Buddha and his Dhamma (critical edition: Ambedkar 2011) he rephrases his theory of religion as a theory of dhamma. As the states in the preface, Buddha's dhamma is the best religion. "No religion can be compared to it" - a statement, which, ironically, is the result of his comparative studies. In a wording that can be read as a meta-paraphrase of Marx's eleventh thesis on Feuerbach ("Philosophers have hitherto only interpreted the world in various ways; the point is to change it"), he writes: "The 
purpose of Religion is to explain the origin of the world. The purpose of Dhamma is to reconstruct the world." (Ambedkar 2011: 171) Dhamma is religion minus its negative, supernatural and mythic aspects, plus its being "aboriginal" (2011: 168); that is, he believed it to have been the original religion of India and the untouchables. In his theory of dhamma he also drew on the notion of the "sacred," which alone could guarantee that a moral order would not be transgressed (Durkheim 2011; see Omvedt 2003: 260).

As religion (or Dhamma) was, for Ambedkar, a precondition for the meaning and preservation of life, the determination and promotion of the good, social life and bonding of the individuals in a community, leaving religion never was an option. Leaving Hinduism was necessary in order to enable religion to do its work for the untouchables. Untouchables would need to "embrace the religion of the community whose kinship they seek." (235) Which community, or which religion would that be?

Ambedkar's announcement of leaving Hinduism opened the marketplace for religions. As much as he was determined to deconvert from Hinduism, he was not in a hurry to convert to another religion. As his personal library shows, he did read himself up on the comparative religion, investigating the different pros and cons of the main religious options available in India. Representatives of different religious communities got in touch with him, and he attended conferences of different religious groups. The archbishop of Canterbury even expressed concern about an auction of religions taking place in India (Jenkins 2007: 455).

Eventually, after World War II Ambedkar mainly concerned himself with Buddhism, even though the Indian branch of Buddhist Mahabodi Society, which was dominated by Bengali Brahmins, had in 1936 expressed shock at his decision to leave Hinduism (Omvedt 2003: 258f). In 1950 Ambedkar undertook tours to Sri Lanka, Burma, and Nepal to study lived Buddhism. Yet, it would take another six years until he and his second wife Savita - a medical doctor in a mass ceremony in Nagpur presided over by a respected old Burmese Buddhist monk publicly recited the Three Refuges and the Five Precepts, thereby formally adopting Buddhism. He then led hundreds of thousands of his followers to take the same step. The next day, on October fifteenth, 1956, he gave a three-hour long speech in Marathi in which he recapitulated his religious trajectory and to defend his decision. "I feel as if I have been liberated from hell," he said (Karunyakara 2002: 246). In one passage he reflects on the long timespan from deconversion to conversion:

... there are some who wonder why I have taken so long to take a decision. In regard to the change of religion. "What have you been doing all 
these years?" They ask. The only reply I can give is this that question of religion is the most difficult and a very serious question. It is a matter of enormous responsibility ...

KARUNYAKARA 2002: $25^{2}$

While Ambedkar does not mention this, we should not forget that he vowed not to die a Hindu. Was it merely an accident that he died less than two months after his conversion? Or did he feel death approaching? This remains a matter of speculation. In this speech, however, Ambedkar shares some results of his research in comparative religion. Here is one main finding, which for him speaks in favor of Buddhism:

The teachings of the Buddha are eternal but even then the Buddha did not proclaim them to be infallible. The religion of Buddha has the capacity to change over time. A quality which no other religion can claim to have.

KARUNYAKARA 2002: 253

Another comparative advantage that made Buddhism attractive to Ambedkar was its basis in reason and an "element of flexibility in it, which is not to be found in any other religion." (Karunyakara 2002: 255)

Ambedkar developed a scheme for a new form of Buddhism in India - he called it Navayana, as an alternative to Theravada and Hinayana. Ambedkar was not the first learned untouchable to adopt Buddhism, and his view of Buddhism shows continuities to earlier Buddhist revivalists such as the Tamil Iyothee Thass (1845-1914) and Laxmi Nasaru, whose book The Essence of Buddhism he republished with a preface in 1948 (Omvedt 2003: 2, 259; Jacobsen 2018: $69-71) .^{4}$

For the present chapter, it is worth recalling that for the mass-conversion event as performed in Nagpur in October 1956 Ambedkar composed a declaration of faith comprising 22 articles that were to be recited by the new Buddhists. The first six of these are actually declarations of deconversion. The first four are statements of "I do not believe in," followed by a series of Hindu deities and avatars. The fifth article reads:

I believe that the idea that the Buddha is an avatara of Vishnu is false propaganda.

BELTZ 2005: 57; see OMVEDT 2003: 262 for a different translation

4 See Beltz (2005) for the development of Ambedkar-inspired Buddhism. 
With this, Ambedkar apparently wanted to make sure that Hindu strategies of inclusivism would not be applied to re-domesticate the new Buddhism as a form of Hinduism. This is, after all, is a line of interpretation, which could seem to be warranted by the Constitution of India. An explanation (II) to paragraph 25 ("Right to Freedom of Religion") reads as follows:

The reference to Hindus shall be construed as including a reference to persons professing the Sikh, Jaina or Buddhist religion, and the reference to Hindu religious institutions shall be construed accordingly. ${ }^{5}$

While this could be read to mean that Hinduism encompasses Sikhism, Jainism and Buddhism, an Ambedkarian reading would probably emphasise the equality of rights for the adherents of these religions. Moreover, the article acknowledges the religion-status for Sikhism, Jainism and Buddhism and does not refer to them as Hindu sects or the like.

\section{Conclusion}

Obviously, Ambedkar was not the first Hindu to leave his native religion. There is a long history of Hindu conversion to Islam, Sikhism and Christianity (see the chapter by Clemens Cavallin in this volume). Apart from individual decisions, these were often motivated and backed up by political circumstances. Yet, the case of Ambedkar is special in different respects. He acted as an individual but also on behalf of the Mahars and other groups of untouchables who he knew would follow him so that his step carried a great responsibility. As an untouchable he had a remarkable career, and through his exceptional international and interdisciplinary education he obtained a much broader horizon than any of his fellow untouchables. Ambedkar's decision to leave Hinduism was based on his own life-experiences and on a penetrating theoretical analysis. His is a case where leaving a religion (not to be confused with leaving religion) was an existential step. It was preceded by unprecedented and provocative acts of burning a Hindu book. He conceived of leaving Hinduism as an act of liberation, but an incomplete one as long as a new religion to convert to had not been identified. This only happened shortly before his death, so that he would remain truthful to his vow of not dying as a Hindu. His study and quest, the time it took from public deconversion to public conversion, covered a period of 21 years. His decision was not based on a revelation or some kind

5 https://www.india.gov.in/sites/upload_files/npi/files/coi_part_full.pdf (accessed 03/o7/2019). 
of transformative experience, but "almost as a scientific project" (Viswanathan 1998: 134) based on critical comparative analysis. His decision was grounded in a post-supernaturalist social and functionalist theory of religion, in which there was no place for belief in deities and the miraculous. He sought to implement his ideas on the nature and function of religion by forming a new blueprint of religious praxis. Nowadays, this Buddhist religion is lived by over five million people in the Indian state of Maharashtra.

\section{References}

Ambedkar, B.R. 2002. The Essential Writings. Edited by Valerian Rodrigues. New Delhi, Oxford: Oxford University Press.

Ambedkar, B.R. 2014a [1989]. Writings and Speeches. Volume 5. Compiled by Vasant Moon. New Delhi: Dr. Ambedkar Foundation, Ministry of Social Justice and Empowerment, Government of India.

Ambedkar, B.R. 2014b. Annihilation of Caste: The Annotated Critical Edition. Edited and Annotated by S. Anand. Introduction by Arundathi Roy. London: Verso.

Beltz, J. 2005. Mahar, Buddhist, and Dalit: Religious Conversion and Socio-Political Emancipation. New Delhi: Manohar.

Cháirez-Garza, J.F. 2018. "B.R. Ambedkar, Franz Boas and the Rejection of Racial Theories of Untouchability." South Asia: Journal of South Asian Studies. 41:2, 281-96.

Coward, Harold G. 2003. "Gandhi, Ambedkar and Untouchability." In H. Coward ed., Indian critiques of Gandhi. Albany: State University of New York Press, 41-66.

Dirks, N.B. 2001. Castes of Mind: Colonialism and the Making of Modern India. Princeton: Princeton University Press.

Jacobsen, K.A. 2018. "Revivals of Ancient Religious Traditions in Modern India." Temenos 54:1, 63-77.

Jaffrelot, C. 2005. Dr Ambedkar and Untouchability: Analysing and Fighting Caste. London: Hurst and Co.

Jenkins, L.D. 2007. "True Believers? Agency and Sincerity in Representations of 'Mass movement' Converts in 1930s India." In D.C. Washburn and A.K. Reinhart, eds, Converting cultures: religion, ideology, and transformations of modernity. Leiden, Boston: Brill, $435^{-463 .}$

Jondahle, S., and Beltz, J., eds. 2004. Reconstructing the World: B.R. Ambedkar and Buddhism in India. Oxford: Oxford University Press.

Karunyakara, L. 2002. Modernisation of Buddhism: Contributions of Ambedkar and Dalai Lama XIV. New Delhi: Gyan.

Keer, D. 1971. Dr. Ambedkar. Life and Mission. Third edition. Bombay: Popular Prakashan. 
Omvedt, G. 2003. Buddhism in India: Challenging Brahmanism and Caste. New Delhi: Sage Publications.

Pandey, G. 2006. "The Time of the Dalit Conversion." Economic and Political Weekly. 41:18, 1779-1788.

Rao, A. 2009. The caste question: Dalits and the Politics of Modern India. Berkeley: University of California Press.

Visvanathan, G. 1998. Outside the Fold: Conversion, Modernity, and Belief. Delhi: Oxford University Press.

Zelliott, E. 2013 [2004]. Ambedkar's World: The Making of Babasaheb and the Dalit Movement. New Delhi: Navayana. 